\title{
THE CONTENT OF PASTORAL COUNCELING AS PRECONDITION OF PROFESSIONALIZATION OF CARITATIVE SOCIAL WORK
}

\author{
Skaidrīte Gūtmane \\ Latvian Christian Academy
}

\begin{abstract}
Pastoral counseling has long history; its roots are found deep in the concept of "shepherding" (or care for the soul, poimenics) which originates in Christ's approach to men. However, interest about various counseling methods today beyond the Church setting is called by expanding of the identity question of the social work profession. Currently social work is done in circles where meaning of religious issues rises above the average in society and clients express their wish to cooperate with social workers who care for their faith and religion. Also it should be noted that more attention is paid to the Church as an institution which is an important provider of social services for the needy, rejected, for orphans, risk families etc. Consequently, the task of the present article is to shed light on pastoral counseling content taking place in professional setting.

KEY WORDS: counseling, structure of human consciousness, imago Dei, Eastern Church fathers, professional qualities of counselor, caritative social work.
\end{abstract}

\begin{abstract}
Anotacija
Pastoracinio konsultavimo istorija gana ilga. Šiuo metu dèmesị ịvairiems, su Bažnyčia susijusiems konsultavimo metodams skatina socialinio darbo profesijos identiteto paieškos. Šiandien socialinis darbas paveikia tas visuomenès grupes, kurioms religija ypač svarbi, yra poreikis bendrauti su socialiniais darbuotojais, kurie rūpinasi savo klientų tikejjimo klausimais. Svarbu pažymèti ir tai, kad Bažnyčia vis dažniau suvokiama kaip institucija, kuri teikia socialines paslaugas skurstantiesiems, atstumtiesiems, našlaičiams, rizikos šeimoms ir pan. Taigi šio straipsnio tikslas - atskleisti pastoracinio konsultavimo turinị profesionalios veiklos kontekste.

PAGRINDINIAI ŽODŽIAI: konsultavimas, žmogaus sąmonès struktūra, imago Dei, Rytų Bažnyčios tėvai, profesiniai konsultanto gebėjimai, karitatyvinis socialinis darbas.
\end{abstract}

DOI: http://dx.doi.org/10.15181/tbb.v67i2.852

\section{Introduction}

Christian pastoral counseling is a professional activity executed by a professional sharing a Christian worldview focused on both spiritual care for and consulting of one or several persons, families and groups by integration of specific Christian resources on the one hand and cognitions of humanities, social sciences and education on the other. The competence of pastoral counselor is interdisciplinary (theology, Patristics, asceticism, philosophy, psychology etc.), however, the key concept in pastoral counseling is played by the Christian anthropological view of man and teaching of deification described by the Eastern Church fathers $\left(2^{\text {nd }}-4^{\text {th }}\right.$ 
cent.). Pastoral counseling helps to improve quality of life of a person as a spiritu$\mathrm{al}^{1}$ being; consequently, its task is to bring people closer to Christ and the Church.

"Pastor" derives from Latin noun pastor "shepherd" and relates to the role of elder within the New Testament. The present-day usage of the word is rooted in the Biblical image of shepherding (feeding the sheep in Old Testament), or to the spiritual feeding of human beings (Jer. 3: 15). In our context it should be emphasized that English translations of the New Testament usually render the Greek noun $\pi$ ouฑ v "care for the soul" as "shepherd". Most frequently it is referred to Jesus (Jesus called Himself "Good shepherd", Jn. 10: 11). Today shepherding or pastoral counseling is executed by a priest (in Eastern Orthodox and Roman Catholic Churches), pastor (in Protestant denominations) or by a certified specialist who has an appropriate education and knowledge in theology as well as professional qualification in pastoral counseling.

The first function of pastoral counseling is to help clients to overcome life difficulties and various crises (delete the phrase of different sorts) of different sorts by opening new opportunities for both relationships and behavior. Consequently the main tasks of the pastoral counseling are: 1) promotion of self-understanding and self-realization, ${ }^{2}$ 2) improvement of communication skills, 3) to promote changes in cognition and behavior, 4) actualization of Christ by which changes of life ways with Christ's help are meant, 5) pastoral support in the given situation (Collins, 1980, p. 23-24).

K. Kiessling, Roman Catholic theologian and psychologist, has emphasized that relationships between pastoral counselor and a client are wrapped in "mutually recognized presence of God in the counseling process" (Kīslings, 2004, 64. lpp.). That ingredient has been described as radically necessary by the well-known $20^{\text {th }}$ century Orthodox theologian and expert in the field Metropolite Anthony of Surozh who spoke about the practice of spiritual leadership: "The first task, duty and function of pastoral counselor is to keep the state of adequacy to himself as deep and selfless as possible, i.e., to receive strength from Christ and the Gospel. From Christ - because He is a Living God Who came to reveal what only $\mathrm{He}$ knows about Himself, about God and about man created by Him according to His image; only He can reveal the real horizon of another person. And that vision

1 „Spritual” in Christian context is related to the work of the Holy Spirit, the third person of the Holy Trinity in man. The Church is hesitant to use the term "spirituality" due to its ambiguity, but speaks about man as a "spiritual" being and his "spiritual" capacities.

2 Concept of self-realization in the Christian context differs from that in traditional sense where man is subject of self-realization. In the Christian context it means realization of God's plan in one's life. 
of man is given to us not only through communication in prayer which poses us face to face with Christ and roots us in His mystery, but also through the Word of the Holy Scripture, which is for us - the Word of God and the Truth of God" (Антоний, Митр. Сурожский, 2012, с. 133).

The second function of pastoral counselor is prayer for the one who trustfully asks for help. However, as Metropolite Anthony of Surozh puts it, prayer "is not mere calling somebody's name taking for granted that God will do all what is needed; to pray for another person means to conceive the person in your own heart and to take him in so deep as to get identified with him, and then hold that person in front of God all the time and everywhere" (Ibid). An example of such attitude is found in "Hassidic stories" by Martin Buber. A young rabbi was asked where does he gets strength to influence every sinner coming to him? He answered: "When someone comes to me and tells me about his life, I step down to him, descend to the very depth of his sin - step by step, and merge roots of my soul with roots of his soul knowing that his sin is also my sin, and I bow before God and confess those very same sins and my patient confesses his sins also with me" (Бубер, 1997, c. 224-225).

Consequently the key to success of and mandatory requirement to the pastoral counselor is to accept the other person as oneself not only objectively, in the academic sense, but in solidarity which means radical unity. Such attitude is called "the condition of the heart of the pastoral counselor" or "his identity mark" (K. Kiessling and Orthodox theologian A. Shmeman).

Spiritual life mistakenly is visualized in terms of fight against evil. We seek to find what's wrong and what the evil to be fought against is. However, pastoral counselor won't be able to feed the client if he will see only the dark side, his sin and evil. Sheperding will be possible on condition of seeing the original beauty of God's image in man in the context of indestructible Divine beauty - still knowing that its beauty has been disfigured by the sin and circumstances. We people are like paintings of some great artists: if we look on some of the world's most precious masterpieces of indescribable beauty which have been damaged by circumstances, from human neglect, hatred, ignorance, our hearts would groan from pain. Only by merge with the Divine beauty found in every man the pastoral counselor is able to evaluate what has been damaged and then work on reception of help for successful move towards client's self-realization. The most important thing is not what has been lost but what can be achieved by enactment of God's will in one's life. B. Tyrell uses the term "existential love" and explains that "to love existentially means to appreciate the gift of unique existence given to all people... To love existenti- 
ally means to love with deep human love transformed by the gift of Christ's love overpouring one's heart" (Tyrell, 1985, p. 65-66). Only then the pastoral counselor finds himself in a balanced, mutually fruitful relationships with the client - because he operates in the territory of the Divine friendship where successful dialogue is established by the presence and power of Christ.

\section{Concept of man in pastoral counseling}

There are basically two sources - the Bible and writings of Eastern Church fathers (ca. $2^{\text {nd }}-7^{\text {th }}$ cent.). It should be noted that anthropology of the Church fathers stems from the Biblical teaching about man merged with elements from the Greek philosophical anthropology. These sources are constructive for a Christian worldview and basically shared by all denominations. They actually were created before the Great schism which separated the West from the East. It's not our task to characterize later denominational developments: they are briefly mentioned along the way.

Anthropology of the Church fathers emphasizes three aspects or conditions. First, it speaks about the so-called first-created man (Adam), made "in the image and likeness of God" (Gen. 1: 26-27). Second, about the Fall when the original nature of man was destroyed by $\sin$ (Gen. 3). Third, about the so-called redeemed man who is capable to step on the path of deification.

Man was created in the image and likeness of God means possession of characteristics of God exclusively in absolute sense, including his free will. However, freedom for God means infinite and indestructible will for good, whereas free will for man denotes his rights to choose between the good and bad. God has endowed men with unlimited freedom: men are even capable, if they wish so, to limit themselves against God and to follow their own will, even daring to stand against God and His will. God made man capable to decide and take sides exactly as He can. Consequently, by creating man as an absolutely free God has tied Himself with his further destiny. This is where the Church, the sacramental establishment on earth by Christ, steps into the picture of pastoral counseling.

The image and likeness of God (imago Dei) is one of the most important themes in anthropology of the Eastern Church fathers. Majority of authors find the image of God within the soul of man or in the highest aspects of the soul - that of consciousness (mind) (Иоанн Дамаскин, преп, 2011, с. 3), others find its reflection in the God's given capacity to make free choice (Максим Исповедник, 2010 , c. 57). Still others find it in the man's unique capacity, namely, immortality 
and creativity (Максим Исповедник, 2010, с. 57). All men share the same essentials although taken separately every man is a unique. Consequences for pastoral counseling are obvious - clients are not subject to the counselor's personal opinion and ambition, or some stiff prescribed agenda, not even mentioning manipulation. They were created by God as beings called to manifest love granted to them in the moment of creation as potential. As children we are longing for mother, and love ties us with her and the family. Later we steps into marriage and it happens that the fruit of love between husband and wife is their child, wrapped in parents' love. Thus love is the key driving force of exchange of generations.

However, man is a being with dual nature. God created man "from the dust of the ground, and breathed into his nostrils the breath of life" (Gen. 2: 7). "Breath of life" should be understood as soul which God gave to man. "Breath of life" in man or his soul raises the man and puts him very close to the Creator. On the one hand, he is made from the earth, "the dust of the ground"; on the other he is a being to whom likeness of God was given as capacity. Consequently his life may unfold within the narrowed-down anthropological value limits, whereas capacity of likeness opens up unlimited horizons both in anthropology and acceptance of values. Therefore pastoral counselor cares for implementation of the key calling of man, i.e., potential to grow from the earthly and material towards the Divine. This must be accepted as the task of life. That's why shepherding is a help to stand on the road leading to deification.

\section{The concept of deification}

According to Eastern fathers teaching about deification is the key concept of Christology (teaching about Christ) and Soteriology (teaching about Salvation). The term "deification" $(\theta \varepsilon \circ \varsigma 1 \zeta)$ is not mentioned in the Bible and people of today may find it strange. The term "salvation" is more wide-spread and better known in the Western Church (Roman Catholicism and Protestantism). By definition the Western term points to salvation from something: be it sin, evil, or hell. "Salvation" (or "delivery") is antonymous to "extinction" (or "getting lost"). The Eastern Church, on the contrary, doesn't take "salvation" as correction of from results of the Fall, as deliverance from the rule of darkness, but chiefly as an implementation of the main goal of life created in the image and likeness of God (i.e., emphasizing inner resources rather than power from outside, incl. moral correction). This is one of the key differences between the Eastern and Western Churches' teaching about deification / salvation. Although the primary function of Christ as Savior or Soter 
stays the same in both East and West, Eastern fathers emphasize necessary efforts of the man - as pointed by the verb. Technically speaking the man is deifying himself through practice of asceticism. Consequently the issue of anthropology in the Christian East was moved onto focus of deification of the fallen man. Deification of man is a central one in the Eastern Orthodox theology, asceticism and mysticism already two thousand years. It is part of its peculiar cataphatic theology (from Greek "to bring God down in such a way as to speak of Him"). As the holy martyr Hilarion (Troicky) has said, "the Church still has its life from the ideal of deification, as it was lived out from the beginning and what illustrious theologians and teachers strived for".

Eastern fathers argue that the idea of deification was taken from the New Testament where it is stated: all people are called to become "partakers of the divine nature" (2.Pet. 1: 4). The Fathers' teaching was based on words of Christ where He called all people as "gods" (Jn. 10: 34; Ps. 81: 6) and cognition of ap. John that people are called to become "children of God" (Jn. 12), and about likeness of God in man (1.Jn. 3: 2): "Beloved, now we are children of God and it has not appeared yet what we shall be." Also ap. Paul in numerous texts explains Biblical teaching about the image and likeness of God in man (Rom. 8: 29; 1.Cor. 5: 49; 2.Cor. 3: 18; Col. 3: 10) and man being a temple of God (1. Cor. 3: 16). Ideas from the New Testament have been later developed by Eastern theologians of the $2^{\text {nd }}$ century (Ignatius from Antioch called Christians being "God-holders" (Игнатий Богоносец, 2005 , c. 2), Irenaeus of Lyon used formulae which emphasized likeness of God in man; theologians of the Alexandrian school - Clement, Origen and Athanasius the

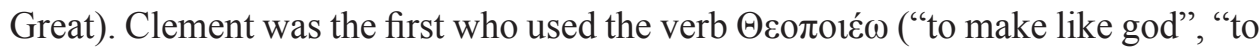
deificate"): "The Word deifies man with its own heavenly teaching." According to Ephraim the Syriac God, creating the man, put into him capacity to become a "created god" (Ефрем Сирин, преп., 2000, с. 3, 31-32). Exactly because men are not able to fulfil the task, God became incarnated: "The Most High knew that Adam wants to become like God, and therefore sent His Son... to grant fulfillment of his wish" (Ефрем Сирин, 1988, с. 69).

In the later Byzantine period the theme of deification was developed by Simeon the New Theologian (9th cent.): "Right because of this Christ came down on earth and became man, accepted our earthly flesh to make us partakers in His Divinity" (Симеон Новый Богослов, 1918, с. 210). Simeon takes faith in positive deification as a key issue in the Orthodox thinking.

For Clement deification is an ethical perfection: man in the state of perfection becomes "capable to see God and to bear similarity with God" (Климент 
Александрийский, 1996, с. 18). Classical definition of deification is given in writings of Athanasius the Great: "(The Word) became flesh with a call to work for deification" (Афанасий Велийкий, свят., 1994, с. 54), "because He (Christ) became man to deify us within Him" (Ibid, c. 19). The idea of deification is present also in writings of the great Cappadocian fathers of the $4^{\text {th }}$ century. Basil the Great has said: "I can't bow before the creature since I myself am creature and I've got a call to become god" (Григорий Богослов, свят., 2007, с. 633). No one among Christian theologians has used the term "deification" so often and consistently as Gregory the New Theologian: "Let us become like Christ because He became like one of us: let us become gods in thanks to Him, since He became a man for us. He accepted the worse in order to give us the best" (Ibid, c. 18). Gregory initiated the cognition that there is direct link between incarnation of God and deification of man. Through His sufferings Christ has deified man by merging human image with the heavenly one (Григорий Богослов, свят., 2008, т. 2, с. 33, 94).

Faith in perfection of human nature through Christ envisages capability of deification in full scope: mind, soul and flesh may be deified, and vice versa - the idea of deification of man envisages faith in Christ being man with perfect mind, soul and flesh.

Deification takes place in the Church through Sacraments (Baptism and Eucharist). This is why pastoral counseling first and foremost is a priestly function. Baptism lays foundation for the re-birth of man subsequent work of God the Holy Spirit through deification in progress and the rebirth of man. Thanks to man's love of God deification is possible: "Love of God is a way to deification" (Ibid, c. 312). Deification is not an intellectual activity; the whole Christian life must take the road of deification in fulfilment of the Gospel law. (Ibid, c. 229). The road to deification leads through active charity: "Express yourself actively - not by doing evil, but by doing good, if you want to be like god" (Ibid, c. 231). If a man becomes generous and charitable, consequently, "Divine in him is his capability to do good... Don't miss an opportunity of deification" (Ibid, c. 259-260).

The road leads through prayer: "What do you want to become?" - Gregory asked his soul. "Do you want to become a god - standing in light face to face with the Almighty God, rejoicing with angels? Go forward, straighten your wings and soar up" (Ibid, c. 229). Through prayer and purification of mind partial knowledge of God is acquired which becomes even more perfect when getting closer to the goal of deification. "God enlightens our mind with the same speed as the lightning shines through our sight." 
As it was mentioned above, deification prescribes human initiative. In its description Simeon uses popular image of iron in fire: in the same way as fire transfers its characteristics over to the iron but doesn't accept its darkness, so the Holy Spirit of God grants men with His incorruptibility and immortality, transforms men into light and offers likeness of Christ (Симеон Новый Богослов, 1917, с. 86-89). Consequently deification - restoration of the original likeness of God in man. Simeon the New Theologian argues that deification is a constantly ongoing process with several stages (typical for cataphatic theology). A man, keeping God's commandments, slowly attains position where sinful dispositions leaves the mind and passions die out; man attains humility and sorrow for his former life, and then Holy Spirit descends upon him (Симеон Новый Богослов, 1982, с. 174). More careful you keep God's commandments, more enlightened and learned becomes your mind. Man is given new eyes and new ears from the Spirit of God, and he sees spiritually and hears spiritually; on even higher stages God becomes for him "everything he wants and beyond it". Step by step man becomes capable to see God and observes also nobility of his own soul, because he is enlightened (Ibid, c. 14). Deification of man and enlightenment with the Divine light and conjugation with Christ is so perfect, that it encompasses whole being, including both the body and limbs.

\section{The concept of body, soul, mind, heart, and reasoning and memory}

Body.

Universally accepted truth in Patristics is that the human soul expresses ultimate essence of man, whereas his body stands lower, consequently it must submit hierarchically under the soul. However, it doesn't mean that Christianity manifests degrading attitude towards the body or flesh. Quite contrary, Christianity by its proclamation of God-Who-Became-Man rejects any sort of spiritualism in whatever form - Platonic, Ne-platonic, Origenic, Gnostic or Manicheic. As the $2^{\text {nd }}$ cent. Christian author puts it, "we must care for the body as if it was the temple of God" (Климент Римский, 1988, c. 90), but Tertullian at the turn of the $2^{\text {nd }}$ and $3^{\text {rd }}$ centuries wrote that the body is "wonderfully created by God", it is "God's masterpiece", "bellows of His breath", "the Mistress of His creation" (Квинт Сертимий Флоренс Тертуллиан, 1994, с. 320). Following the teaching of the Church fathers body is a house for the soul, and the soul uses feelings of the body as windows through which to get into contact with the material world. Sometimes the body is 
called "chariot of soul", "an organ of the soul". The body must be taken care of since it is a tool of the soul (Варсануфий Великий и Иоанн, преп., 1905, с. 333).

Does human body have some organs which could be taken as a place of concentration of powers of the soul, or all bodily organs serve the soul equally? Usually human brain is thought of as the organ of intellectual activity (Иоанн Дамаскин, 2011, c. 19), whereas heart is seen as the organ of all other powers of the soul. ${ }^{3}$ The soul permeates all organs of the body; some of them are specifically created as a "home" for feelings: eyes and respective brain nerves serve as organs of sight, ears and its nerves serve as organs of hearing, tongue, palate and its nerves are organs of taste, but the whole nervous system works as foundation of feelings (Дамаскин, преп., 2011, с. 18).

Heart as a center of spiritual life has been located by numerous ascetic theologians, who have created theory and practice of the so-called wise heart prayer. They see heart as an organ for mystical perception of God: "The blessings of God writes spiritual laws and heavenly mysteries on tablets of heart," says Macarius the Great. "Heart is a leading and ruling organ over all organs of the body. And blessings of God rule, once they have entered the heart, over all other organs and all intentions of the man. Because mind and all intentions and all trust are located there" (Макарий Египетский, преп., 2002, с. 224). All essential events of the spiritual ascension take place in the heart, i.e., the soul is conceived by the Spirit, it gets into contact with the spiritual realm and meets God there. And vice versa - in the heart evil thoughts, murder, lust, stealth, lies, blasphemy (Mt. 15: 19) are born. Consequently the task of asceticism is to purify one's heart, to deliver it from all sinful intentions. In a way the process of deification - as described by Eastern fathers, reminds cognitive-behavioral approach in clinical social work (Berlin, 2002).

\section{Soul.}

By term "soul" Christian anthropology means the invisible - contrary to the bodily aspect of man. Sometimes in the Bible the term is used to denote any living being (Gen. 2: 19, 9:12), the life principle or phenomena of life contained in the body (Gen. 9: 4), and blood (Lev. 17: 11), also human life (Gen. 19: 17). The same meaning of the word is testified also in the New Testament.

From latin transcendo, ,, to step over”. Self-transcendence is a move over one's own ego, cognition of personal ties with the Divine in morals. 


\begin{tabular}{|c|c|c|c|c|c|}
\hline \multirow[t]{3}{*}{$\begin{array}{l}\text { THINKING } \\
\text { is energy of } \\
\text { the mind } \\
\text { activity. } \\
\text { sinergy of the } \\
\text { Spirit of God } \\
\text { and human } \\
\text { mind. Results } \\
\text {-inspiration, } \\
\text { revelation, } \\
\text { disc overies, } \\
\text { intuition }\end{array}$} & \multirow[t]{3}{*}{$\begin{array}{l}\text { WILL } \\
\text { is spiritual } \\
\text { peculiarity of } \\
\text { the soul, } \\
\text { snergy-the } \\
\text { power } \\
\text { satisfying } \\
\text { needs of the } \\
\text { soul }\end{array}$} & \multirow[t]{3}{*}{$\begin{array}{l}\text { HEART is } \\
\text { spiritually } \\
\text { emotional } \\
\text { organ of the } \\
\text { mystical } \\
\text { content of the } \\
\text { soul, main } \\
\text { object of } \\
\text { pastoral and } \\
\text { pedagogical } \\
\text { influence }\end{array}$} & $\begin{array}{l}\text { REASONING } \\
\text { is activity of } \\
\text { the Spinit } \\
\text { which } \\
\text { manife sts } \\
\text { itself in the } \\
\text { sphere of } \\
\text { mind and } \\
\text { unity of all } \\
\text { power of the } \\
\text { soul. }\end{array}$ & \multirow[t]{3}{*}{$\begin{array}{l}\text { CONSCIOUS } \\
\text { NESS } \\
\text { is spiritually } \\
\text { em otional } \\
\text { regulator } \\
\text { organ of the } \\
\text { life of soul; } \\
\text { place of } \\
\text { activity of } \\
\text { Spirit of G od }\end{array}$} & \multirow{3}{*}{$\begin{array}{l}\text { MIND } \\
\text { is a place where } \\
\text { personality and } \\
\text { unity-in-one } \\
\text { (hypostas i) of } \\
\text { man dwells } \\
\text { encompassing } \\
\text { wholeness of } \\
\text { man: spirit soul, } \\
\text { body. Mind is the } \\
\text { highest capacity } \\
\text { to rule over } \\
\text { one self and by it } \\
\text { the man is tie d to } \\
\text { God. If themind } \\
\text { is touched by } \\
\text { God, it may } \\
\text { become divine }\end{array}$} \\
\hline & & & $\begin{array}{l}\text { Regulates } \\
\text { muman values, } \\
\text { goals, self } \\
\text { evaluation and } \\
\text { self respect. }\end{array}$ & & \\
\hline & & & $\begin{array}{l}\text { Leads to } \\
\text { personality. } \\
\text { Man in unity } \\
\text { with God is a } \\
\text { free perso nality. }\end{array}$ & & \\
\hline
\end{tabular}

Soul in Eastern Patristics is described as the "unbodily, dispassionate, immortal essence of wisdom" - a living, born, wise essence by which the organic and sensitive body acquires power of life (Григорий Нисский, 2003, с. 214). In conceptualization of the inner structure of the soul the Eastern Church fathers have followed the Socratic - Platonic division in psychology. Soul consists of three

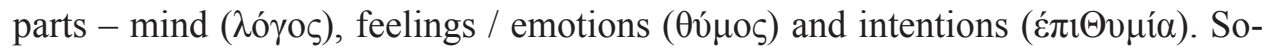
metimes they are related as: rational, irritable and yearning. Simeon the New Theologian wrote that "soul is like a smart workshop where in the center dwells power of rationality, but in unity with rational there are intentions and irritations (in Russian раздражительность) (Симеон Новый Богослов, 1918, с. 392-394).

How soul comes into being? Was it created before any human body or simultaneously with it? Or is it "mature" right from the beginning, or unfolds its capacities similarly to the body development? According to Gregory of Nyssa soul was created together with the body. Along with development of the body also the soul "develops and increases". In the moment of the making of body there is only one "power of growth and feeding", similar to roots hidden in soil. Later, when the plant gets into contact with light, "the gift of sensitivity arises". When the plant gets matured "the power of mind flowers and bears fruit that the power of man is capable of” (Григорий Нисский, 2003, с. 45).

Is the soul unbodily by its nature? Yes, in regards to the human body, but no - in regards to God. As John of Damascus wrote, "only God is of unbodily nature; angels, demons and souls are unbodily only because of God's grace" (Иоанн Дамаскин, 2011, с. 12). Generally accepted in the tradition of Christian thinking 
is immortality of soul. However, immortality is taken in relative sense rather than absolute and ontological, because the destiny of the soul rests in hands of God. Only God is immortal in absolute sense; the soul is immortal only insofar as it gets closer to the immortality of the Divine. Justin Martyr wrote: "Soul lives because God wanted it to be alive, and therefore it can cease to live if God will want it stop living" (Иустин Философ, 1995). Furthermore, Theophil of Antioch considers man not to be immortal by nature, but capable to achieve immortality (Феофил Антиохийский, 1988).

Mind

"Mind" (voús) occupies important place in Christian anthropology. The term is often used by ap. Paul. Mind is not a synonym to soul: Anthony the Great emphasizes that "mind is not a soul but rather a gift of God who saves the soul. The Godrecognizing mind goes ahead of the soul and advices to neglect the mundane and to love the eternal, immaterial values so that man still being in flesh would strive for the Divine in his mind. Mind filled up with love of God - this is salvation of the human soul" (Антоний Великий, 1988, с. 94). Mind is hidden deep in the depths of heart, hidden deep in depths of soul and living ordinarily; it may be substituted by the so-called mind of the soul and stay unearthed. Man conceives to know his spiritual mind only by stepping on the ascetic way with the goal to reveal his spiritual mind and to deify his soul. After spiritual mind gets fully revealed in its glorious light and multi-sidedness, the man reaches perfection.

Mind is an instrument of spiritual sight: "Eyes see, but mind grasps the invisible" (Ibid, c. 94). The organ of rational thinking is human brain, whereas the organ of mind (wisdom) is heart. Therefore a man whose "heart is full of love of God has also an enlightened heart and he sees God with his whole mind" (Ibid, c. 128). Mind occupies priority position in the mystical progress of man towards God, whereas the soul follows after. "Man is the only creature who gets to know God and only he is capable to grasp the ungraspable, to see the invisible and to hold the unholdable" (Симеон Новый Богослов, 1917, с. 70-79).

Human mind can become enlightened. Evagrius Ponticus wrote that there are two lights: first, "the most blessed light of the Holy Trinity" and, second, light of human mind, enlightenment of mind (Евагрий, авва, 1994, с. 74). There are some similarities between the light Divine and that of human enlightenment: mind is created in the likeness of God, and the light of mind is "relative to Him" (Ibid, c. 2). During the prayer the man who has acquired insensitivity himself becomes "like a light" (Ibid, c. 15).

Human mind can be focused either on God or some other direction. Church fathers, particularly they who dealt with the "wise activity", always stressed that 
the mind can have different "coloring" relative to objects it is focused onto. The world is made of different elements, and so the mind - being fully focused on elements of the visible world, it loses its simplicity and becomes fragmented and multifaceted, and vice versa - once the mind (re)turns to God, contemplates the One, it also becomes whole (Daniel, Patriarch of the Romanian Orthodox Church, 2008, p. 17). This is how different positions of the mind are described by Maximus the Confessor: "Mind, being focused on God through prayers and love, becomes wiser, stronger, and graceful, loves people, and indeed possesses all qualities of God; whereas if the mind is focused only on material possessions, it becomes beastly and rough" (Максим Исповедник, 2010, с. 127). Human mind, once it has lost its spirituality and simplicity, is no way different from the mind of the soul. Then the mind is transferred from the depths of the heart over to brain and gets divided among multiple intentions and speculations about the fundamentals of the world - while forgetting God. In order to remember God it has to be taken back into heart and be locked there.

\section{Reasoning}

There is one more instrument in the soul - reasoning or intellect. Obviously mind and reason have become synonyms in secular use when people are left without conscience that they've got the utmost capacity - to contemplate (созерияать in Russian). The main and original task of man according to God's purpose has been interrupted communication with God (богообщение in Russian), therefore there is inbuilt capability in him to pray and to contemplate and by this to penetrate into spiritual essence of things and phenomena. Whereas reasoning is an instrument which secures contacts with the material world, helps to understand the visible, to analyze experience.

The location of mind in the firstborn man before the Fall is in his heart, whereas "territory" of reasoning was brain. The highest powers of the soul - wisdom and energy of the mind - converge and act from within heart as one - this condition is described as purity of heart. It is characteristic of the completely healed soul of an ascetic. Adam lost this power of inner unity when he forbade God, consequently, capacities of his mind split away from his heart and he lost his contemplation. This was the birth of a "common man oriented on outwardly cognition, separated from his heart" (Софроний (Сахаров), 2009, с. 203-209). Overall tendency in modern culture is separation of the heart and intellect and the idea of the "culture of heart" is lost (Ibid, c. 229). Consequently the primary function of mind is reduced to reasoning and tendency to care for the concrete, mundane and abstract (heartless). Mind has lost its primeval task to keep the uninterrupted cultural contact with God. Mind gets tired of the amount of information generated by reasoning; this creates 
difficulties to grasp fundamentals of spiritual life. If the mind stems from reasoning, life "goes round through circles of passion" (Григорий Синаит, 1999, с. 26). That situation is typical for many clients.

\section{Memory}

Memory is one of the mysterious human capacities. Should it be tied to the mind or is it just a capacity of reasoning? John of Damascus relates it to reasoning. Both emotions and thinking are capacities of the soul, and what has been accumulated in soul, is preserved in memory - he speaks about the so-called mundane memory which contains memories about events and phenomena in the material world. It is true also in regards to the so-called "bad memories" of offences. According to the teaching of Eastern fathers remembering of offences poison whole mind and soul.

However, there is another type of memory related to both mind and heart that of "remembrance of God". Pastoral counseling is aimed at rejuvenation of this type of memory. It is contained in heart, it is internally whole and simple and its only object is God. Once the remembrance of God is activated it drives out mundane memory of the soul (i.e., it drives out resent). As Isaac the Syriac puts it: "Remembrance of God takes out memories about the visible" (Исаак Сирин, преп., 1911, с. 405).

Return to the normal condition of the soul is made possible only by repentance and confession of sins, i.e., by restructuring of the soul in deification which opens up the way to the ultimate goal of manhood. Pastoral counseling points to spiritual goals, teaches practical methods how to reach unity with Creator - since man was not made self-sufficient. Confession and prayer - these are the key instruments of the soul healing.

\section{Repentance and confession of sins as foundation of the spiritual life}

The concept of Imago Dei is the fundamental platform for practical pastoral counseling. On the other hand the capacity of self-transcendence ${ }^{4}$ as an instrument of self-knowledge is important for enforcement of positive dynamics in man's life. Self-transcendence is a driving force of positive changes and it is linked to repentance and confession of sins when the whole value system undergoes changes and reorientation. "Through confession," says Simeon the New Theologian, "men become sons of the Divine light. Because the light, indeed, causes light, and they become children of God, as it is written, like gods. That is possible because of the

4 From latin transcendo, „to step over”. Self-transcendence is a move over one's own ego, cognition of personal ties with the Divine in morals. 
blessing given to them" (Симеон Новый Богослов, 1917, с. 83). In some other passage he addresses his readers: "Take pains... to lighten the torch of the mind in your soul and become like suns shining over the earth... in order to become like gods." (Ibid, Гимн 13).

The Greek word for repentance and confession of sins and reorientation of values is $\mu \varepsilon \tau \alpha v o 1 \alpha$ - reckoned as the ,greatest word in the New Testament" (Walden, 1896, p. 3) - means "change of mind, a change in the trend and action of the whole inner nature, intellectual, affectional and moral". Usually it is translated as „repentance" (e.g. Mk. 1: 4, 6: 12; Mt. 4: 17; Acts 17:30). The process of repentance and confession destroys sinful attitudes and dispositions, receives strength from God for a completely new start. Man experiences God's help in the process. Confession is invaluable gift to humanity; it secures radical transformation of energies within a man (Хоружий, 2005, с. 191). It is foundation for restoration of a spiritual being. Confession is the first step in spiritual life and it is important to keep the confessional direction during whole life span. Sisoes the Great ( $4^{\text {th }}$ cent.) was asked: "Father, what should I do?" Sisoes answered: "Rise!" The man replied: "I have tried to rise several times, but always fell back." The holy one answered: "Rise again!" Unto what the man cried out: "And how many times should I rise?" Sisoes said: "Until the day of your death” (Благолюбие, 2010, с. 543).

Repentance and confession of sins is more than just the first step, it plays an important anthropological role by taking to the next step in spiritual progress that of conscious war with the so-called pathologies of the soul or passions. There are many passions around - gluttony, lust, greed, melancholy, anger, depression, ignorance, pride being the most important. Every sin practiced regularly may lead to pathology if it has become a necessity and truly the second nature of man. Man must know his passions, must learn ways how his mind can be lost (for somatic or demonic reasons, as described by the Orthodox theologian and psychiatrist J. C. Larsche) (Ларше, 2011, c. 65-117). Knowing that man is not able to overcome passions alone, pastoral counselor advices to proceed in spiritual path within the Church where means of grace, the Sacraments, are available.

\section{Professional qualities of the pastoral counselor}

Professional duties and challenges of pastoral counselor are correlated with his personal characteristics. This is not a profession for all. A person without empathy or a person incapable to listen to others will not be a successful counselor. Today the profession is even more challenging because of the need of interdisciplinary approach and skills to make difference between various fields of knowledge. Ho- 
wever, the main challenge is ability to show trust in the client so that he/she finds courage and joy of creativity in self-realization as a spiritual being.

A client must not be handed over to some prescribed agenda of pastoral counseling scenario setting. Genuine love and trust rises from recognition that every man is a Mystery for others. And genuine vision of otherness doesn't arise from reasoning of the professional counselor, but rather from the sight of his heart. Consequently trust in communication between the two stems from faith in Image of God within oneself - without that positive setting pastoral counseling won't be possible.

On the other hand, how is it possible that in the era of rational science and technologies professional pastoral counseling is still rooted in faith in God and trust in people? It's not a frivolity and it is not naivety. It is deep conviction that there are no people without human empathy and there are no people in whom their best dignity won't be found and activated. The attitude is rooted in principles described in the Gospel. Just one example: a woman found in adultery was taken to Jesus, and she deserved severe punishment. However, Christ didn't punish her, He didn't condemn the act. He didn't look onto the woman through dark glasses of her sin. He looked into her soul and saw capacity for some new, completely different life - yes, He saw purity of her heart and knew that she is not dead spiritually. When the woman was taken for punishment, when she understood that death penalty is unavoidable, she got back to her real spiritual senses. At that moment the message was clear - sin kills, sin destroys, and she accepted the blunt truth - according to laws of the day she was to be killed with thrown stones. She knew: if there was a chance to start a new life, she will never touch what causes death. And Christ saw that. He said to those around: "Let the one who is without a sin throw the first stone." And all left. He stayed alone with the woman and said to her: "Where are they who condemned you? They are gone. Also I'm not condemning you - do not sin anymore!” (Jn. 8).

This is why the term authentic trust in man has been proposed for positive description of conviction - there is indestructible dynamics of life force in every man, and it is the lack of self-consciousness rather than obstacles and circumstances that work against realization of that ontological foundation. On the other hand, selfpedagogy is a work of the pastoral counselor with a set goal to permit the work of the Holy Spirit within him. Theophan the Recluse compares it with tuning of the musical instrument: attention is to be paid to each string until they create perfect sound together.

Self-pedagogy is not an easy task. Shaping of reason is rather easy; everyone can develop his intellectual capacities. Heart according to the teaching of the Fathers is a complex spiritual organ, submitted to changes in different state of mind. The only consistent discipline capable to keep the heart in harmony is prayer, i.e., 
speaking to God as a Person.

The main obstacle in the process of self-pedagogy is neglect towards the unpleasant. It narrows down one's heart by renunciation to share the heavy load of others. Metropolite Anthony of Surozh uses illustration - corals are the most fragile creatures in the sea. In order to defend themselves against destruction they encase in hard stuff we call corals, and inside that self-defense fortress they finally die. The same happens with pastoral counselor if he decides to narrow his heart, to protect himself against pains and hardships of the other. He probably would share advices, but he has killed the gift of love given by Christ. Once Elder Paisius was asked: "What does it mean - if you have a heart?" He answered: "First, if you have a heart, you are able to love God; second, if you have heart, you are capable to feel empathy; third, if you have a heart, you are patient; fourth, if you have a heart, you can be strong. When we say heart, we do not mean an organ of the body but rather the ability of self-sacrifice and to love deeply" (Паисий Святогорец, блаж. памяти старец, 2009, с. 206).

There are no two equal counseling situations. Pastoral counselor as a spiritual personality respects freedom of any other man. He is conscious that God can and wants to save everyone. But He cannot save without the one's personal will and acceptance. As Maximus the Confessor has emphasized - every man has rights to reject his salvation. Neither salvation nor spiritual life can be executed in compulsory manner: only they will be saved who express personal will to follow Christ (called ascetics in Eastern tradition). The main task of the pastoral counselor is to open perspectives for successful changes with the help of Christ. He respects human freedom but he has no rights to narrow the anthropological border of the God's given grace.

Received 20140610 Approved for publishing 20140701

\section{References}

Berlin, S. B. (2002). Clinical Social Work Practice: A Cognitive - Interactive Perspective. NY, Oxford: Oxford University Press.

Collins, G. R. (1980). Christian Counselling. England: Milton Keynes, Word Publ.

Daniel, Patriarch of the Romanian Orthodox Church. (2008). Confessing ther truth in love: Orthodox Perception of Life, Mission and Unity. Bucarest: Basilica.

Florovskis, G. (2009). Austrumu Baznīcas tēvi. Jūrmala: Latvijas Kristīgā akadēmija.

Kīslings, K. (2004). Jūs sveicina mīlestība. Jūrmala: Latvijas Kristīgāa akadēmija.

Līdums, G. (2011). Dievs spogulī: Refleksijas par dievlīdzību un tās praktisko nozīmi teoloǵijāà. Rīga: Agape Latvija.

Jānis Pakāpnieks, sv. (2013). Pakāpieni uz debesīm. Jūrmala: LKrA.

Trub, H. (1951). Heilung aus der Begegnung. Stuttgart: MKV.

Tyrell, B. (1985). Christotherapy: An Approach to Facilitating Psychospiritual Healing and Growth. Clinical 


\section{THE CONTENT OF PASTORAL COUNCELING AS PRECONDITION OF...}

Handbook of Pastoral Counselling.

Антология Восточно-христианской богословской мысли: Ортодоксия и гетеродоксия. (2009). В 2-х т.

Москва, СПб.: РХГА, Никея.

Антоний, Митрополит Сурожский. (2012). Человек перед Богом. Киев: Quo vadis.

Афанасий Велийкий, свят. (1994). Творения 64 m. Москва: Свято-Троицкая Сергиева Лавра.

Благолюбие. (2010). Москва: Святая гора Афон.

Бубер, М. (1997). Хасидские предания. Москва: Республика.

Варсануфий Великий и Иоанн, преп. (1905). Руководство к духовной жизни. Санкт-Петербург.

Восточные Отиы Церкви IV века. (1916). Москва.

Вышеславцев, В. (1929). Сердие в христианской и индийской мистике. Париж.

Григорий Богослов, святитель. (2007). Творения в 2-х m. Москва: Сибирская Благозвонница.

Григорий Нисский. (2003). Большое огласительное слово. Киев: Пролог.

Добротолюбие. (1988). Т. 1, 4. Paris: YMCA-Press.

Евагрий, авва. (1994). Аскетические и богословские трактаты. Москва: Сергиев Посад.

Ефрем Сирин, преп. (2000). Творения. Николаев: Літопис.

Игнатий Богоносец. (2005). Послание к Ефесянам 9. В: Ранние Отиы Церкви. Москва: Сибирская Благозвонница.

Иоанн Дамаскин, преп. (2011). Точное изложение православной веры. Москва: Отчий Дом.

Иоанн Дамаскин, преп.(2002). Источник знания. Москва: Индрик.

Иоанн Златоуст, преп. (2005). Беседы на книгу Бытия. Киев: Свято Успенская Почаевская лавра.

Иларион (Алфеев), митроп. (2013). Духовный мир Исаака Сирина. Москва: Изд-во Московской Патриархии РПЦ.

Исаак Сирин, преп. (1911). Слова подвижнические. Москва: Сергиев Посад.

Иустин, философ и мученик. (1995). Сочинения. Москва.

Квинт Сертимий Флоренс Тертуллиан. (1994). Избранные сочинения. Москва.

Климент Александрийский. (1996). Падагог. Москва: Учебно-информационный экуменический центр ап. Павла.

Климент Римский. 2-е Послание к Коринфянам. (1988). В: Ранние Отиы Церкви. Антология. Брюссель.

Макарий Египетский, преп. (2002). Духовные слова и послания. Москва: Индрик.

Максим Исповедник. (2010). Вопросы и недоумения. Москва: Святая гора Афон.

Ларше Ж. К. (2011). Исиеление психических болезней. Москва: Изд-во Сретенского монастыря.

Паисий Святогорец, блаж. памяти старец. (2009). Слова, т. 5. Страсти и добродетели. Москва: Монастырь св. апостола и евангелиста Иоанна Богослова.

Симеон Новый Богослов. (1918). Главы богословские, умозрительные и практические. Вып. 1-2. Москва: Сергиев Посад.

Симеон Новый Богослов. (1917). Божественные гимны. Москва: Сергиев Посад.

Симеон Новый Богослов. (1982). Слова, вып. 1-2. Москва: Сергиев Посад.

Феодорит Кирский. (2003). Трудные места Священного Писания. В: Творения блаженного Феодорита, епископа Кирского. Москва.

Феофил Антиохийский. (1988). К Автонику. В: Ранние Отиы Церкви. Брюссель.

Хоружий, С. С. (2005). Очерки синергийной антропологии. Москва: Ин-тут синергийной антропологии. 
